\title{
Group INSURANCE AND REINSURANCE BusinesS IN THE LEgal Relations WITH AN INTERNATIONAL ELEMENT
}

\section{Petr Dobiáš \\ CEVRO INSTITUT, Department of Private Law \\ petr.dobias@vsci.cz}

DOBIÁŠ, Petr. Group Insurance and Reinsurance Business in the Legal Relations with an International Element. International and Comparative Law Review, 2016, vol. 16, no. 2, pp. 209-220. DOI: 10.1515/iclr-2016-0025.

\begin{abstract}
Summary: Currently, no internationally unified legal regulation of group insurance contracts and reinsurance contracts is available. As a result, a national legal regulation determined according to conflict-of-law rules is applied to both types of contracts in legal relations with an international element. The differences between national legal regulations could be overcome through the application of optional instruments, namely the Principles of the European Insurance Contract Law and the Principles of Reinsurance Contract Law.
\end{abstract}

Keywords: insurance, reinsurance, insurer, policyholder, insured.

\section{Introduction}

The Principles of European Insurance Contract Law (further referred to as "the PEICL") were first published in 2009. The first edition consisted of three parts (Part One - Provisions Common to all Contracts included in the Principles of European Insurance Contract Law, Part Two - Provisions Common to Indemnity Insurance and Part Three - Provisions Common to the Insurance of Fixed Sums). In 2015 the PEICL were published for the second time, the final wording being amended by another three parts (Part Four - Liability Insurance, Part Five - Life Insurance and Part Six - Group Insurance). The arrangement of legal regulations concerning insurance as set out in the PEICL differs from Czech Act No. 89/2012 Coll. of the new Civil Code (further referred to as "the NCC"), the content of the General Provisions of the NCC corresponding with the First, Second, Third and Sixth Part of the PEICL. In the NCC life insurance (Section 2833 to 2843) and liability insurance (Section 2861 to 2867) is systematically arranged into individual subsections which follow the General Provisions (Section 2758 to 2832). The subject of the analysis and comparison will be the applicability of the PEICL as an instrument allowing to overcome the differences between national legal regulations of group insurance ${ }^{1}$ in the case of effecting group

1 The NCC covers group insurance in Section 2827 within the General Provisions on the 
insurance with an international element (e.g. between a policy holder and an insurer with a place of business on the territory of different states). Regulation (EC) No 593/2008 of the European Parliament and of the Council on the law applicable to contractual obligations (further referred to as "the Rome I Regulation") does not comprise the conflict-of-law rule to determine the law applicable to group insurance. Provisions of Article 3 of the Rome I Regulation allow the choice of the applicable law of a particular state, which does not preclude contractual parties from incorporating by reference non-State standards into their contracts (compare recital 13 of the Rome I Regulation).

In autumn 2015 a new project group was set up with the aim to develop the Principles of Reinsurance Contract Law (further referred to as "the PRICL"), which are to be completed in 2018. Unlike the PEICL, the PRICL do not contain mandatory provisions. Compared to the PEICL, the PRICL are not a complex regulation containing principles of reinsurance - they are model rules. As it is obvious from the title of the PRICL, their application shall not be limited solely to Europe. The PRICL may be applied when settling litigation between insurers and reinsurers, in the case where the direct insurer and the reinsurer incorporate the PRICL into their contract, or if they authorize arbitrators to use them to decide a dispute concerning reinsurance.

Insurance of Persons. K Haas states correctly that such systematic classification could lead to the wrong conclusion that group insurance can be concluded only within the framework of the insurance of persons, although group insurance may as well be concerned with group insurance of a bond, group insurance of damage liability and group insurance of credit cards (DVOŘÁK, Jan, FIALA, Josef, ŠVESTKA, Jan: Občanský zákoník, komentár (Civil Code, commentary) volume VI, Section 2521 to 3081, Prague: Wolters Kluwer, 2014, p. 673). To compare, in the German Insurance Contract Act of 2008 [Act adopted on 23rd November 2007, came into effect on 1st January 2008 (BGBl. p. 2631), further referred to as "the GICA"] there is a separate regulation on group insurance within the provisions on giving consent with life insurance (Section 150 par 2 - collective group insurances within the framework of company pension schemes) and within the provisions on the termination of health insurance (Section 206 par 4 and Section 207 par 2). Greek Act No 2496/97, on Insurance Contract within Article 29 par 3 only states that in a group insurance it is possible to negotiate a different time limit for paying the surrender value than the one given for individual insurance within the same provisions. In that the Greek regulation differs from Article L 132-23 of the French Insurance Code of 1976 (further referred to as "FIC"), which, besides two exceptions, excludes paying the surrender value in case the insurance benefit is subject to termination of labour activity. In Articles L 141-1 to L 142-5 the French regulation provides for the basic issues connected with group insurance (definitions, exclusion of the insured from the insurance, obligations of the policyholder etc.). In the UK the Insurance Act of February 12, 2015 (effective from August 12, 2016), in Article 13 provides for the remedies for fraudulent claims within group insurance and in Article 18 it deals with the applicability of provisions on concluding group insurance contracts. The above stated examples of Acts can be used to prove that legal regulation of group insurance in national legal orders provides just for the sub-issues related to this type of insurance. 


\subsection{Definition of Group Insurances}

Under Article 1:201(7) of the PEICL “contracts for group insurance" are contracts between an insurer and a group organiser ${ }^{2}$ for the benefit of group members ${ }^{3}$ with a common link to the group organiser (e.g. an employer concluding group insurance for his/her employees or a professional chamber concluding group insurance for its members).${ }^{4,5} \mathrm{~A}$ contract for group insurance may also cover the family of the group members. In Section 2827 par 1 of the NCC it is stated more precisely that if insurance covers the members of a particular group or their families and their dependants, where applicable, the contract does not have to contain the names of the insured persons if the insured persons can be identified without any doubts no later than at the time of the insured event. The authors of the NCC thus prevented possible any ambiguities connected with determining the scope of the people covered by group insurance. Further, in Section 9 of the same provision the PEICL define "Elective group insurance" as a group insurance under which group members are insured as a result of personal application or because they have not refused the insurance. From the point of view of Czech legislation such provision is not surprising since under Section 2827(2) of the NCC the consent of the insured is not required in group insurance. However, under German legislation written consent of the insured, except for collective group insurance within the occupational pension schemes, is required on pain of annulment. ${ }^{6}$

\subsection{Characteristics of Provisions Regulating Group Insurance in the PEICL}

The PEICL contain a relatively small number of provisions which are mandatory for all contracting parties of the insurance contract (Articles 1:102 second

2 From the legal point of view a sole insurance contract is, considering the insurance-technical perspective, viewed as consisting of as many insurance relationships as equals to the number of insured group members (BENKEL, Gert, A., HIRSCHBERG, Günther: Lebensund Berufsunfähigkeitsversicherung, Munich: C. H. Beck, 2011, marginal no. 3).

3 Neither the NCC nor the PEICL define a group. Further, they do not provide for the number of group members, compared to Article 1496 of Turkish Act No 6102/2011 (effective from July 1,2012 ) of the Business Code which regulates that a group is formed by a minimum of 10 persons but the decrease in number of members in the course of the duration of the contract does not result in its termination.

4 The reason for concluding group insurance is usually the possibility to negotiate a decrease in premiums paid by the policyholder for more insured persons (e.g. insurance concluded by an employer for more employees) considering the premiums paid by the insured/policyholders in the case they would conclude individual insurance contracts related to the same insurance risk.

5 The revoked provision in Section 3 of Act 37/2004 Coll., on Insurance Contract defined group insurance as "a private insurance that applies to a group of insured persons specified in more detail in the insurance contract, the identities of which are usually not known at the time of the conclusion of the contract".

6 W. Schnepp a Y. Gebert in VEITH, Jürgen, GRÄFE, Jürgen, GEBERT, Yvonne: Der Versicherungsprozess, Baden Baden: Nomos, 2016, marginal no. 53. 
sentence, 2:104, 2:304, 13:101, 17:101, 17:503 and Articles sanctioning fraudulent behaviour). All other provisions of the PEICL are unilaterally mandatory, i.e. they cannot be derogated from to the detriment of the policyholder, the insured or the beneficiary. An exception to this rule (in the case of group insurance) is found in the option to derogate from any unilaterally mandatory provision of the PEICL in relation to the policyholder who possesses personal characteristics specified in Article 13 par 27 (b) or (c) of Regulation No 2009/138/ES (Solvency II) ${ }^{7}$

\subsection{Special Provisions for Group Insurance comprised in the PEICL}

\subsubsection{Group Insurance in General}

a) Applicability

Contracts for group insurance are subject to the PEICL on the condition that the group organiser and the insurer agreed on their application. According to the PEICL group insurance is classified as either accessory (Chapter I. 3.2) or elective (I. 3.3.).

\section{b) General Duty of a Group Organiser}

In the course of negotiation and performance of the contract for group insurance, the group organiser shall act dutifully and in good faith taking account of the legitimate interests of the group members for he or she is in a position similar to the one held by an insurance agent. In the case where the group organiser breaches the duty, he or she shall be liable for damage. The group organiser shall submit all relevant notices for the group members issued by the insurer and shall inform them of any change in the contract (including the termination of the

7 It concerns insurance of the so called "large risks", specifically:

a) risks within category 14 (credit) and 15 (guarantee/suretyship) in Part A of amendment I to Solvency II Directive if the policyholder professionally pursues industrial or commercial activity or one of the liberal professions, and the risk relates to this activity;

b) risks within category 3 (land vehicles other than railway rolling stock), 8 (fire and natural forces), 9 (other damage to property), 10 (motor vehicle liability), 13 (general liability), and 16 (miscellaneous financial loss), in Part A of amendment I to Solvency II Directive, in so far as the policyholder exceeds the limits of at least two of the following three criteria:

i) balance sheet total of 6.2 million Euros;

ii) net turnover within the meaning of the Council Directive 78/660/EHS from July 25, 1978, based on Article 54 par 3(g) of the Contract on Annual Accounts of Companies (note: although this directive was repealed by Directive 2013/34/EU of the European Parliament and of the Council of June 26, 2013 on annual financial statements, consolidated financial statements and related reports of certain types of undertakings, amending Directive 2006/43/EC of the European Parliament and of the Council and repealing Council Directives 78/660/EEC and 83/349/EEC, the reference in Article 13 par 27(c) of Solvency II Directive had not been updated): 12,8 million Euros;

iii) average number of employees during financial year: 250 . 
contract). The reason for such regulation is the limited access of group members to information on insurance.

\subsubsection{Accessory Group Insurance}

a) Application of the PEICL

Accessory group insurance enables additional members (of the insurance) to join (or more precisely be joined to) the concluded group insurance automatically on a gradual basis. If necessary, other provisions of the PEICL shall apply mutatis mutandis to accessory group insurance. If e.g. a beneficiary is to be designated, it will usually be a group member, not a group organiser, who designates the beneficiary, although the application of Article 17:102 par 1 of the PEICL $^{8}$ would suggest the opposite conclusion. ${ }^{9}$ In this regard Article 17:102 par 1 of the PEICL differs from Section 2829 of the NCC which stipulates, only for cases where death of an insured is the insured event, that the policyholder may determine the ultimate beneficiary, either by his name or by his relationship to the insured person.

b) Information Duty

If a group member joins the group, a group organiser shall inform the member without any necessary delay on:

- the existence of an insurance contract,

- the extent of cover,

- $\quad$ any precautionary measures and other requirements for preserving cover, and

- the claims procedure.

Thus, the information duty does not have to be fulfilled before the member joins the group. The burden of proof regarding whether the group member obtained information as stated in the previous paragraph lies on the group organiser (e.g. an employer who hired new employees).

c) Termination of the Contract by the Insurer

Within the framework of accessory group insurance provisions the PEICL sets out special derogations for some cases related to the termination of the insurance contract. From the below stated overview it is evident that the termination concerns individual group members whose reason to terminate the contract is given, and does not automatically relate to all members as a group.

8 Text of Article 17:102 par 1 (sentence 1) of the PEICL states: "The policyholder may designate one or more beneficiaries of the insurance money and may change or revoke such designation, unless the designation has been declared irrevocable."

9 J. Norio-Timonen in BASEDOW, Jens, BIRDS, John, CLARKE, Malcolm, COUSY, Hermann, HEISS, Helmut, LOACKER, Leander: Principles of the European Insurance Contract Law, Cologne: Sellier/Otto Schmidt, 2016, p. 358. 
The exercise of the right of termination by the insurer after the occurrence of the insured event shall only be regarded as reasonable if it is limited to the exclusion from cover of the group member to whom the insured event occurred.

In the case that the policyholder or the insured intentionally violated the duty to adopt preventive measures or the insurance risk had been aggravated, the exercise of the right of termination by the insurer shall only have the effect of excluding those group members from the insurance cover who had not taken the required precautionary measures or whose risks were aggravated, as the case may be.

In the case where the conveyance of the insured property had already been effectuated, the termination of the insurance contract shall only have the effect of excluding only those group members who have conveyed their title to the insured property from cover.

d) Right to Continue Cover - Group Life Insurance

If a contract for accessory group life insurance is terminated or if a member leaves the group, the coverage ends after three months or with the expiry of the contract for group life insurance, whichever takes place earlier. When this occurs, the group member shall have a right to the equivalent coverage under a new individual contract with the insurer concerned without a new assessment of the risk (e.g. a sportsman suffers an injury with lasting consequences and subsequently ceases to be a member of a sports association providing insurance for sportsmen).

The group organiser shall inform the group member in writing without undue delay about:

- the imminent termination of his cover under the group insurance contract,

- his/her right to coverage through the conclusion of a new individual insurance contract and

- how to exercise this right.

If a group member has indicated his intention to conclude a new individual insurance contract, the contract between the insurer and the group member shall continue as an individual insurance contract at a premium calculated on the basis of an individual policy at that time without taking into account the current state of health or age of the group member. ${ }^{10}$ The regulation in question apparently draws on the regulation comprised in Section $178 \mathrm{~m}$ of the Austrian Insurance Contract Act of 1959 (further referred to as "the AICA") ${ }^{11}$, which provides for better protection of the insured in that it sets a one-month period for

10 This provision is compatible with Section 2828 of the NCC which allows the insurer to inquire on the state of health of the insured only with the consent of the insured.

11 Federal Act from December 2, 1958, published under No 2/1959 of the BGB. 
exercising the right to conclude a new insurance contract, the given period not running until the insurer notifies the insured that he or she can conclude insurance under the same circumstances as those that applied for group insurance.

\subsubsection{Elective Group Insurance}

a) Definition of Elective Group Insurance

Elective group insurance is deemed to be a combination of a framework contract $^{12}$ between the insurer and the group organiser and individual insurance contracts concluded within such a framework by the insurer and the group members. ${ }^{13}$

The PEICL apply to the individual insurance contracts where the group organiser and the insurer have agreed on their application but, except for provisions defining group insurance and obligations of the group organiser, the PEICL do not apply to the framework contract.

b) Alteration of Terms and Conditions

Alteration of terms and conditions of the framework contract shall only affect the individual insurance contracts if effectuated in compliance with the requirements of Articles 2:603 of the PEICL (Alteration of Conditions of the Insurance Contract), 17:303 (Adjustment of Premium and Benefits Payable) and 17:304 (Alteration of Contractual Insurance Conditions), which shall be applied on group insurance as appropriate.

c) Continuation of Coverage

Termination of the framework contract or cessation of membership on the part of an individual group member shall not have any effect on the insurance contract between the insurer and the group member.

\subsection{Law Applicable to Reinsurance}

Article 7 of Regulation Rome I does not apply to contracts on reinsurance and on insurance contracts covering other than large insurance risks outside the $\mathrm{EU}^{14}$ and thus in these types of contract the law applicable shall be determined by the general conflict-of-law rules provided for in Rome I (provisions of Articles 3 and 4) in the following way:

12 Note: Framework contract is not an insurance contract since it only determines the insurance scheme.

13 In German jurisprudence this type of group insurance is referred to as quasi group insurance.

14 M. Fricke’s opinion (compare Fricke, M.: Das internationale Privatrecht der Versicherungsverträge nach Inkrafttreten der Rom-I-Verordnung, Versicherungsrecht No 10/2008, p. 448 ) that it is an editorial error has been rejected by jurisprudence (compare e.g. Gruber, U., P.: Insurance Contracts publ. in Ferrari, F., Leible, S.: Rome I Regulation - The Law Applicable to Contractual Obligations in Europe, Sellier, Munich, 2009, p. 123). 
- choice of law made by parties under provisions of Article 3 of Rome I,

- if under provisions of Article 3 of Rome I no choice of law is made, then law of the country where the party required to effectuate the characteristic performance of the contract has his habitual residence or place of business shall apply,

- where it is clear from all the circumstances of the case that the contract is manifestly ${ }^{15}$ more closely connected with a country other than the country of the party required to effectuate the characteristic performance of the contract, the law of that other country shall apply.

Within jurisprudence and legal practice it is still a matter of controversy whether the characteristic performance in case the choice of applicable law had not been made shall be effectuated by the reinsurance company or the primary insurer. Authors supporting the opinion that the law of the place of business of the primary insurer shall apply draw on the fact that the existence of the contract on reinsurance depends on the existence of the insurance contract in question. In the authors' opinion the reinsurer shall eventually provide only pecuniary performance, therefore it is the primary insurer, directly guaranteeing insurance coverage in the insurance contract, who shall effectuate the characteristic performance. ${ }^{16}$ To support this opinion, M. Fricke states that the Solvency II Directive draws on the fact that the risk which is the subject of the reinsurance contract finds itself within the place of business of the branch of the primary insurer and therefore, in order to prevent confusion, it is recommended to apply the law of the place of business of the primary insurer. ${ }^{17}$ According to

15 The word "manifestly" was inserted in Rome I Regulation additionally, compared to provisions of Article 4 par 5 of the Rome Convention, on the Law Applicable to Contractual Obligations of 1980 in order to accentuate the exceptional use of the escape clause and thus prevent its excessive use by courts of the EU Member States.

16 Compare D. Czernich in HEISS, Helmut, CZERNICH, Dietmar: EVÜ - Das Europäische Schuldvertragsübereinkommen - Kommentar, Vienna: Orac, 1999, p. 106-107, FRICKE, Martin: Das internationale Privatrecht der Versicherungsverträge nach Inkrafttreten der Rom-I-Verordnung, Versicherungsrecht, 2008, No 10, p. 446 and A. K. Schnyder and P. Grolimund in REITHMANN, Christoph, MARTINY, Dieter: Internationales Vertragsrecht, Cologne: Verlag Dr. Otto Schmidt, 2015, p. 1435. M. Fricke maintains his opinion even in the commentary to Rome I Regulation and presents a number of logical arguments to support the applicability of the law of the state where the primary insurer and the reinsurer have their place of business [comp. RAUSCHER, Thomas (ed.): Europäisches Zivilprozeß- und Kollisionsrecht: Kommentar (Rom I-VO, Rom II-VO), Munich: Sellier, 2011, p. 345-347]. Finally, he again concludes that it is appropriate to apply the law of the place of business of the primary insurer considering that it is the territory of the given state where the primary insurer concludes the majority of the contracts against which reinsurance is provided.

17 RAUSCHER, Thomas (ed.): Europäisches Zivilprozeß- und Kollisionsrecht: Kommentar (Rom I-VO, Rom II-VO), Sellier, Munich, 2011, p. 343-347. The same, D. H. Wendt in RAUSCHER, Thomas (ed.): Europäisches Zivilprozeß- und Kollisionsrecht: Kommentar (Rom I-VO, Rom II-VO), Cologne: Otto Schmidt, 2015, p. 350-352. 
the second group of authors ${ }^{18}$ it is the pecuniary performance of the reinsurer that shall be considered the characteristic performance in a reinsurance contract. Nevertheless, this is a purely academic debate as the majority of contemporary reinsurance contracts comprise provisions on the choice of law. The problem is that national legal orders usually do not comprise national legal regulations on reinsurance contracts and therefore a general regulation of contract law, which disregards the specificities of such contractual obligations, is applied to this type of contracts. Besides, some legal regulations exclude the application of national legal regulation of insurance contracts on reinsurance contracts. ${ }^{19}$ Therefore, this area offers space for the introduction of the PRICL which could serve as a manual for concluding reinsurance contracts.

\subsection{The Applicability of the PRICL to the Conclusion of Reinsurance Contracts} with an International Element

The authors of the PRICL do not wish for the incorporation of these principles into the national legal regulation or their taking on the form of a treaty or an EU regulation. The PRICL are to be used in combination with the commercial contract principles (and commercial usage), such as the UNIDROIT Principles for International Commercial Contracts from 2010 serving as a model during the development of the PRICL. The application of the PRICL is not confined to international reinsurance contracts, and therefore they can be applied to national reinsurance contracts as well.

The use of the PRICL is limited by mandatory standards that make part of the public law regulation governing the insurance industry. ${ }^{20}$ The contractual parties are free to modify the text of the PRICL. The PRICL accentuate the need for respecting good faith at the conclusion of reinsurance contracts. The text of the PRICL will comprise the definition of a reinsurance contract, the draft of which has now been subject to a debate by the project group. ${ }^{21}$ There has also been a debate over the insertion of the arbitration clause at the end of the text of

18 Compare BĚLOHLÁVEK, Alexander: Římská úmluva, Nařízení Řím I (Rome Convention, Rome I Regulation), Volume I, Prague: C. H. Beck, 2009, p. 1180, GRUBER, Urs, Peter: INSURANCE CONTRACTS. In FERRARI, F., LEIBLE, S.: Rome I Regulation - The Law Applicable to Contractual Obligations in Europe, Munich: Sellier, 2009, p. 112 or HEINZE, Christian: Insurance contracts under the Rome I Regulation, Nederlands Internationaal Privaatrecht, volume 27, 2009, No 4, p. 452.

19 It concerns e.g. Article L111-1 of the FIC, Section 209 of the GICA, Section 186 of the AICA and Section 101 par 1(1) of the Swiss Federal Act on Insurance from April 2, 1980 (as effective in January 1, 2011).

20 From the viewpoint of international private law these mandatory rules from the domain of financial law will usually be regarded as overriding mandatory provisions.

21 Under the draft Article No 1.2.1. of the PRICL the term "Contract on Reinsurance" refers to a contract under which one party, the reinsurer, in consideration of a premium, promises another party, the reinsured, cover against the risk of exposure to insurance and/or reinsurance claims under a contract of insurance. 
the PRICL as it is expected that disputes over reinsurance are resolved under the PRICL in arbitration in states which enable settlement of disputes based on the rules chosen by the parties to the dispute. ${ }^{22}$

\subsection{General Provisions of the PRICL}

Currently, the draft General Provisions of the PRICL have been debated over by members of the project group, primary insurers and reinsurance companies. The PRICL are interconnected with the UNIDROIT Principles for International Commercial Contracts from 2010 but they differ in that the PRICL can be applied to national contracts (i.e. without the international element) as well. In Article 1.1.3. the PRICL enable the parties to agree on an exclusion of the application or on the modification of some provisions. The formulation of this provision is based on the fact that if a primary insurer and a reinsurer choose to apply the PRICL for their reinsurance contract, exclusion of the application of all principles within the PRICL instead of just some of them is unacceptable. ${ }^{23}$ Under Article 1.1.4 the Parties shall be bound by any usage to which they have agreed and by any practices which they have established between themselves. A trade usage which is regularly known to and observed by parties to a reinsurance contract shall be taken into account when interpreting the terms of the contract. Such a provision is not surprising and it gives consideration to the fact that the PRICL represents the general model of the best usage applied when concluding reinsurance contracts. As stated above, Article 1.1.5 of the PRICL regulates that the application of the PRICL shall not restrict the application of mandatory rules of national law and rules of international contracts. Thus, we can sum up that the application of the PRICL in legal relations with an international element shall be limited by the agreement of the Parties, usage (within the meaning of Article 1.1.4), by mandatory rules of law applicable in accordance with rules of private international law and by international treaties. Nevertheless, in the case of a dispute between the primary insurer and a reinsurer it may be difficult to determine the content of usage to which the Parties have agreed and the practices which they have established between themselves. ${ }^{24}$

\subsection{Rights and Obligations of the Reinsurer and the Reinsured}

The draft Article 2.1.1. of the PRICL emphasizes that in the process of arrangement, conclusion and performance of the reinsurance contract, as well

22 Typically, it will concern states which incorporated Article 28 (Rules Applicable to the Substance of Dispute) of the UNCITRAL Model Law on International Commercial Arbitration from June 21, 1985, with amendments as adopted in July, 7, 2006 (United Nations documents $\mathrm{A} / 40 / 17$, annex I and A/61/17, annex I) in their legal orders.

23 Comments of H. Heiss on Article 1.1.3 adjoining the draft PRICL from September 13, 2016.

24 Compare this issue with BURLING, Julian, LAZARUS, Kevin: Research Handbook on International Insurance Law and Regulation, Cheltenham: Edward Elgar, 2011, p. 149. 
as in the case of termination of a reinsurance contract the Parties to the contract have obligations expressly provided for in the PRICL, the applicable law or the UNIDROIT Principles for International Commercial Contracts from 2010. The Parties to the contract are enabled to adjust their rights and obligations by themselves if the PRICL, or the applicable law does not provide for otherwise (Article 2.1.2 of the PRICL). The respective provisions in fact reiterate General Provisions of the PRICL, and therefore their modification or exclusion in the course of further discussions may be presumed. Further, the PRICL define the principle of Utmost Good Faith in the following way: Utmost Good Faith signifies honesty and transparency in the process of exchanging information and requires that none of the Parties provides a significantly distorted interpretation or refuses to inform of essential facts that the Party has been or should have been aware of, would the Party have acted with due diligence. It has been considered that the application of this principle will be prevented from exclusion since its application has key importance for reinsurers who are frequently dependent on information regarding insurance risks which provide them with reinsurance. In the case that the contractual Party breaches the principle of Utmost Good Faith, such a Party shall be obliged to rectify damage inflicted upon the other Party depending on the circumstances of the case and seriousness of the damage. With regard to the above stated the reinsured is obliged to provide the reinsurer with complete and truthful information on all substantial circumstances concerning the insured insurance risks. A substantial circumstance is defined as a fact with a possible influence on the decision of a reasonable and circumspect reinsurer whether to conclude a reinsurance contract. Under Article 2.2.1 of the PRICL in case there arises a doubt whether a particular circumstance should have significant importance for the conclusion of a reinsurance contract, the burden of proof lies with the reinsurer. The reinsurer is thus entitled to ask the reinsured to provide all necessary information, data and documents concerning the insured insurance risks and damage incurred. The details of this obligation are usually provided for in the reinsurance contract. Naturally, the information duty of the reinsured comprises the obligation to inform the insurer in due manner and time on the insured events including information on a substantial rise in the risk of damage that should be covered by the reinsurer. Nevertheless, as a general rule, failure to meet this obligation will not result in withholding performance by the reinsurer, except if the breach of information duty by the reinsured would cause him excessive damage. The reinsured is entitled to provide benefits regarding all insured events covered by reinsurance, while keeping his power to compromise claims and litigate over benefits without any intervention from the part of the reinsurer. The reinsurer is obliged to provide benefits regarding all claims covered by the reinsurance in accordance with the follow the fortunes principle. ${ }^{25}$

25 The instructive determination of the follow the fortunes clauses can be found e.g. in the ruling of the U. S. District Court for the Southern District of New York in Aetna Casualty and Surety Company v. Home Insurance Company - 882 F. Supp. 1328 (S.D.N.Y. 1995) March 
The reinsured is obliged to ask for the consent of the reinsurer to provide performance, if they had agreed so previously. In the case that the reinsurer wrongfully withholds his consent, he shall indemnify the incurred damages. Under Article 2.4.4. the burden of proof regarding the wrongfulness of the reinsurer's refusal to provide consent lies with the reinsured.

\section{Conclusion}

The PEICL are an optional instrument developed in order to overcome the obstacles connected with the cross-border conclusion of insurance contracts. At the same time, they are an outcome of a compromise, their authors coming from states with Anglo-Saxon as well as the Continental legal systems. Developed by a Project Group on a Restatement of European Insurance Contract Law, the PEICL belong in the Common Frame of Reference, and therefore provisions of the EU Directives, serving as an instrument of harmonization of legal regulations of the EU Member States and accentuating the protection of the weaker contractual party (the consumer, the policyholder and the insured), are reflected in their provisions. From the above stated it may be presumed that the PEICL will assert themselves in the domain of group insurance, where the PEICL represent a balanced standard of an optional regulation, being an outcome of legal comparison by renowned experts, theoreticians as well as practitioners. The legitimacy of their application is also supported by the fact that group insurance has not been given a complex treatment in the examined national legal orders (note: the French regulation being an exception in this regard).

Currently, the PRICL are being shaped by drafters with some of the regulations not yet provided with precise formulation. Therefore it is too early to evaluate the impact of the PRICL on a relatively closed reinsurance sector. Nevertheless, the project group has been making an effort to develop a draft of a so called soft law that would balance the interests of primary insurers and reinsurance industries and thus it is also too early to speculate on the importance of the PRICL for the conclusion of international reinsurance contracts. Considering the fact that the PRICL are closely connected with the UNIDROIT Principles for International Commercial Contracts of 2010 (note: some provisions have been included in the PRICL without almost any alteration) it will be necessary that the primary insurers and reinsurers accept not only the application of the PRICL in their contractual relations, but, to a large extent, the application of the UNIDROIT Principles for International Commercial Contracts of 2010 as well.

27, 1995. Since in the United States the follow the fortunes doctrine is not implied into reinsurance contracts, its proposed regulation within the PRICL is considered relevant (compare the analysis of relevant judicature in the United States covered in article HALL, ROBERT, M. Should Follow the Fortunes/Settlments be implied into Reinsurance Contracts, available online at http://www.robertmhall.com/articles/FolForImpliedArt.pdf) 